\title{
THE OVERVIEW OF DENGUE HEMORRHAGIC FEVER IN EAST JAVA DURING 2015-2017
}

\author{
Gambaran Kejadian Penyakit Demam Berdarah Dengue di Provinsi Jawa Timur Tahun 2015-2017
}

\section{Dewi Putri Dayani}

Department of Epidemiology, Faculty of Public Health, Universitas Airlangga, dewi.putri.dayani2015@fkm.unair.ac.id

Corresponding Author: Dewi Putri Dayani, dewi.putri.dayani-2015@fkm.unair.ac.id, Department of Epidemiology, Faculty of Public Health, Universitas Airlangga, Dr. Ir. H. Soekarno, Mulyorejo,Surabaya, East Java, Indonesia, Postal Code 60115

\section{ARTICLE INFO}

Article History:

Received March, $18^{\text {th }}, 2019$

Revised April, 25 ${ }^{\text {th }}, 2019$

Accepted July, 17 ${ }^{\text {th }}, 2019$

Published online January, 28 ${ }^{\text {th }}, 2020$

\section{Keywords:}

dengue hemorrhagic fever;

incident rate;

case fatality rate;

east java;

profile

\section{Kata Kunci:}

demam berdarah dengue;

angka kesakitan;

angka kematian;

jawa timur;

profil
How to Cite (APA): Dayani, D. P. (2020). The overview of dengue hemorrhagic fever in East Java Province of 2015-2017. Jurnal Berkala Epidemiologi, 8(1), 35-41. https:/dx.doi.org/10.20473/ jbe.v8i12020.35-41

\begin{abstract}
Background: Dengue Hemorrhagic Fever (DHF) is an infectious disease caused by the dengue virus which spreads more widely and the morbidity rate increases every year in East Java Province. DHF transmitting vector is widespread in residential areas and in public places, population density, population mobility, increasing urbanization. Purpose: This study aims to describe the number of cases, Incidence Rate (IR), Case Fatality Rate (CFR), and the peak incidence of DHF in East Java Province in 2015-2017. Method: This study is a descriptive approach study with a population that is all East Java residents who are at risk of suffering from dengue. This study uses a total population technique that involves all DHF cases recorded in the East Java Provincial Health Profile for 2015-2017. The data used are secondary data obtained from the Health Profile of East Java Province in 2015-2017, namely the number of DHF cases, gender, morbidity and mortality rates due to DHF. Data were analyzed using IR and CFR formulas. Results: The number of DHF cases in East Java in 2015 to 2017 fluctuated. DHF morbidity rates have increased in 2016 while 2017 has decreased. The mortality rate in East Java in 2015-2017 has decreased. DHF events often occur in male sex. Conclusion: DHF is a vector-borne disease with rapid spread. The occurrence of dengue hemorrhagic fever every year there is an increase in cases and deaths of almost all districts / cities in East Java.
\end{abstract}

C2020 Jurnal Berkala Epidemiologi. Published by Universitas Airlangga. This is an open access article under CC-BY-SA license (https://creativecommons.org/licenses/by-sa/4.0/)

\section{ABSTRAK}

Latar Belakang: Jumlah kasus Demam Berdarah Dengue $(D B D / D H F)$ di Indonesia mengalami fluktuasi tiap tahunnya dan cenderung mengalami peningkatan dan perluasan sebaran wilayah yang terjangkit. Angka kejadian DBD di Provinsi Jawa Timur cukup tinggi dengan angka kesakitan dan angka kematian yang diatas target nasional.Tujuan: Penelitian ini bertujuan untuk menggambarkan jumlah kasus, Incidence Rate (IR), Case Fatality Rate (CFR), dan puncak kejadian DBD di Provinsi Jawa Timur tahun 
2015-2017. Metode: Penelitian ini menggunakan pendekatan deskriptif dengan populasi yang digunakan adalah seluruh penduduk Provinsi Jawa Timur yang memiliki risiko menderita penyakit DBD. Penelitian ini menggunakan teknik populasi yang melibatkan seluruh penderita DBD yang tercatat di Profil Kesehatan Provinsi Jawa Timur tahun 2015-2017. Data yang digunakan dalam penelitian ini yaitu data sekunder yang diperoleh dari Profil Kesehatan Jawa Timur tahun 2015-2017 yaitu jumlah kasus DBD, jenis kelamin, angka kesakitan dan angka kematian akibat DBD. Data dianalisis menggunakan rumus IR dan CFR. Hasil: Jumlah kejadian DBD di Jawa Timur tahun 2015 hingga 2017 mengalami fluktasi. Angka kesakitan DBD mengalami peningkatan tahun 2016 sedangkan tahun 2017 mengalami penurunan. Angka kematian di Jawa Timur tahun 2015-2017 mengalami penurunan. Kejadian DBD sering terjadi pada jenis kelamin laki-laki. Kesimpulan: DBD termasuk penyakit akibat vektor yang penyebarannya cepat. Kejadian demam berdarah dengue setiap tahunnya terjadi peningkatan kasus dan kematian hampir seтиа kabupaten/kota di Jawa Timur.

(C2020 Jurnal Berkala Epidemiologi. Penerbit Universitas Airlangga. Jurnal ini dapat diakses secara terbuka dan memiliki lisensi CC-BY-SA (https://creativecommons.org/licenses/by-sa/4.0/)

\section{INTRODUCTION}

Dengue Hemorrhagic Fever (DHF) is a rapidly spreading disease. In Indonesia, the number of its cases have fluctuated anually, and it tends to experience an increase and expansion in the distribution of the affected areas. The number of dengue disease reached 78.13 cases per 100,000 people in 463 districtss/cities in 2016. The mortality rate was reduced to 0.79 percent. The outbreak of DHF occurs almost anually in different places. DHF is expected to continue to increase, and the spread is increasingly widespread (Ministry of Health RI, 2017).

Epidemiology is the study of the occurences and frequency distributions according to epidemiological variables (people, time, and place). The researchers sought to determine the risk factors (determinants) of these occurences in a population group. Epidemiology employ the size (parameter) of a simple disease that is a measurement of the calculating number of sick individuals in a population. The frequently utilized epidemiological measurements in DHF control activities consist of Incidence Rate (IR), Case Fatality Rate (CFR), Attack Rate (AR), and Free Larva Index (ABJ) (Ministry of Health RI, 2017).

The incidence of dengue in East Java is high, with morbidity and mortality rates that are above the national target. The DHF incidences occurred in East Java in 2016 reached 64.80 per 100,000 populations. It increased from 2015 by 54.18 per
100,000 people (East Java Provincial Health Office, 2016).

The Case Fatality Rate (CFR) of DHF reached $1.30 \%$ in 2017. In 2017 DHF cases decreased compared to the previous year, yet awareness of the surge in cases in the following years needs to be improved. The most influencing factor in the transmission of dengue fever in East Java includes internal factors, such as the behavior of the community in the prevention of dengue disease. Other contributing factors include climate change, population density, population mobility, urbanization, economic growth, environmental sanitation conditions, and the availability of clean water (East Java Provincial Health Office, 2017).

Based on data of DHF Prevention and Control Program (P2DBD) of East Java, DHF outbreaks occur annually in East Java. It suggested that East Java is an endemic area of DHF. East Java's high population density and high population mobility contribute to the widespread of dengue in East Java (East Java Provincial Health Office, 2018).

Figure 1 suggested that the incidence of DHF rate increased in 2016 from 20,832 to 25,339 cases. The incidence rate declined in 2017 to 7,866 cases. An informant from P2DBD program manager stated that DHF's spreading factors consist of high population density and population mobility habits in controlling Aedes aegypti mosquitoes. There are several techniques for controlling dengue disease, including environmental management or manipulation of 
mosquito breeding sites and individual protection against mosquito bites. People with lack of environmental hygiene are at risk of suffering dengue fever (East Java Provincial Health Office, 2018).

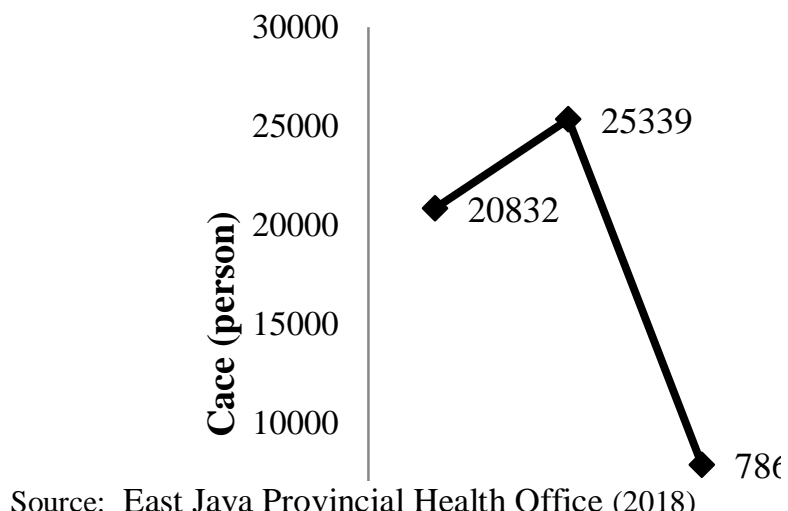

Figure 1. Trend of DHF incidents in East Java during 2015-2017

In spite of inappropriate community environmental management, society prefers chemical prevention of dengue (Ernawati, Bratajaya, \& Martina, 2018). The recorded data that was programmed by P2DBD East Java Provincial Health Office suggested that the incidence and mortality rates of DHF from 2015 to 2017 in East Java were still above the target. The Free Larva Index $(\mathrm{ABJ})$ did not meet the national requirement since the $\mathrm{ABJ}$ of East Java reached $87.49 \%$ in 2017. The low rate of ABJ suggested that the program of eradicating mosquito nests by draining puddle, burying or recycling grabage, and employing larvicide; as well as maintaining larvaeeating fish, and planting plants such as basil, lavender, cereals, and others known as Mosquito Source Reduction (PSN 3M Plus) did not run optimally. The East Java communities did not get satisfying results in controlling DHF as the achievement of the PSN indicators indicated it. The socialization of the program has been carried out, but it was not comprehensive as well as it was not a priority across programs (Dinkesprov Jatim, 2018).

DHF cases become high if the presence of mosquito larvae is found in the environment. The larvae usually live and breed in various places such as puddle or containers that can hold water inside and outside the house. Mosquitoes infected with the Aedes Aegypty virus and its bites will cause the spread of dengue disease (Nurrochmawati, Dharmawan, \& Pawito, 2017). A research conducted by Rahmawati, Joko, \& Nurjazuli (2018) stated a close correlation between the existence of outdoor mosquito breeding sites, $3 \mathrm{M}$ habit (closing, burying, and draining water reservoirs) and dengue disease.

An analysis of an epidemiological frequency measurement as a basis for controlling dengue disease requires to be carried out since managing DHF is strictly related to its vector eradication. The vector eradication has been carried out by the government with the PSN 3M Plus program. Indicators of the program include Incidence Rate (IR), Case Fatality Rate (CFR), and the LarvaeFree Rate (Kemenkes RI, 2017). This study aims to describe the number of cases, IR, CFR, and the peak incidence of DHF in East Java during 20152017.

\section{METHODS}

This research employed a descriptive approach to describe the number of cases, Incidence Rate (IR), Case Fatality Rate (CFR), and the peak incidence of DHF in East Java during 2015-2017.

The research utilized the entire population of East Java who were positively infected by dengue disease in 2015-2017. This study employed a total population technique involving all dengue cases recorded in the health profile of East Java during 2015-2017. The data that were involved was secondary data on the incidences of dengue hemorrhagic fever that was obtained from the health profile of East Java during 2015-2017. The variables that were applied in the study included the number of dengue cases, gender of DHF patients, morbidity, and mortality rates due to DHF. The analysis calculation of this study employed the IR and CFR formulas as follows:

$$
\begin{aligned}
& \text { total incidence in a } \\
& I R=\frac{\text { certain periode of time }}{\text { total population in a }} \\
& \text { certain periode of time } \\
& C F R=\frac{\text { total mortality }}{\text { total case }} \times 100 \%
\end{aligned}
$$

Research activities include the collection, processing of library materials to the preparation of research reports conducted from January to March 2019. 


\section{RESULTS}

\section{Overview of Incidence Rate, Case Fatality Rate, and the peak incidence of dengue hemorrhagic fever in East Java during 2015-2017}

Men mostly suffered the dengue incidence in East Java from 2015 to 2017, yet the number of female sufferers was almost equal to that of men. In 2017 there was a decrease in cases, yet the men patients were still higher $(54.08 \%)$ (Table 1$)$. All districts/cities in East Java were at risk of contracting dengue. The districts/cities with the highest incidence of dengue were Pacitan District in 2015, Sidoarjo District in 2016 and Sampang District in 2017. Districts/cities in the Province which had the lowest number of cases in 2015 were Gresik District, Mojokerto District, and Blitar. In 2016 the lowest cases rate occurred in Mojokerto, Batu, and Ngawi District. Meanwhile, in 2017, the lowest case rates were in Blitar District, Magetan District, Pasuruan (Table 2).

The DHF Incidence Rate in 2015 was 53.60 per 100,000 people, increasing in 2016 to 64.80 per 100,000 people and decreasing in 2017 to 20 per 100,000 people. Its because of the DHF Incidence rate was over than our national rate standard $\leq 49$ per 100,000 population (Figure 2). DHF Case Fatality Rate (CFR) is the percentage of deaths due to dengue in a certain period. The target indicator is to reduce the DHF mortality rate to less than 1\%. From 2015 to 2017 East Java did not reached the target indicator. From 2015 to 2017, East Java did not reach the target indicator. In 2015, the CFR was $4.40 \%$, it decreased from 2016 to 2017 by $1.40 \%$ and $1.30 \%$. The rate suggested that the CFR from DHF in East Java from 2015 to 2017 was quite high because the rate was over than our national rate standard of 100,000 populations and decreased in 2017 to 20 per 100,000 people. The results were above the national target, i.e., $\leq 49$ per 100,000 people (Figure 2).

Based on data from the East Java Provincial Statistics Agency the number of rainy days in East Java in 2015 was 132 days, in 2016 was 223 days, and in 2017 was 174 days. The amount of rainfall reached 2024.70 in 2015, 2976.80 in 2016, and 1696.50 in 2017. The data suggested that the highest number of rainy days and the highest amount of precipitation was in 2016, which is in line with the increasing number of dengue cases in 2016 (East Java Provincial Bureau Statistics, 2018).

\section{DISCUSSION}

Overview of Incidence Rate, Case Fatality Rate, and the peak incidence of dengue fever in East Java during 2015-2017

The dengue sufferers in 2015-2017 mostly were men, although the cases decreased in 2017, still the men as sufferers were higher than women. This research was related with the research conducted by Novrita, Mutahar, \& Purnamasari (2017), stated that there was a correlation between gender and the incidence of dengue disease. The study noted that male was more vulnerable and riskier in suffering from dengue because the immune response in women is better than men as women produce more cytokines than men. On the other hand, according to the study that was conducted by Francisco, Kaunang, \& Kekenusa (2018) stated that the DHF incidence was dominated by women $(70 \%)$ compared to men (30\%). The reason was $90 \%$ of the Aedes aegypti mosquitoes flying around houses, including around damp spaces, bedrooms, toilets, bathrooms, and kitchen. Women mostly do their daily activities around these areas, causing them more vulnerable to be infected with DHF.

The Incidence Rate (IR) of DHF suggested the number of new cases/occurrences of dengue in a population. IR is the number of people suffering from DHF divided by the total population in a certain period, which was then multiplied by a constant. In the DHF controlling and prevention program, some indicators must be achieved, i.e., the percentage of districts/cities with DHF morbidity rates less than or equal to 49 per 100,000 people (Ministry of Health RI, 2017).

Table 1

Dengue Hemorrhagic Fever cases based on Sex in East Java during 2015-2017

\begin{tabular}{lrrrrrr}
\hline \multirow{2}{*}{ Sex } & \multicolumn{7}{c}{ Years } \\
\cline { 2 - 7 } & \multicolumn{2}{c}{2015} & \multicolumn{2}{c}{2016} & \multicolumn{2}{c}{2017} \\
\cline { 2 - 7 } & $\mathrm{n}$ & $\%$ & $\mathrm{n}$ & $\%$ & $\mathrm{n}$ & $\%$ \\
\hline Male & 9,893 & 50.37 & 13,409 & 52.91 & 4,254 & 54.08 \\
Female & 9,744 & 49.62 & 11,930 & 47.08 & 3,612 & 45.92 \\
\hline Total & 20,832 & 100.00 & 25,339 & 100.00 & 7,866 & 100.00 \\
\hline
\end{tabular}


Table 2

List of Districts/Cities with the Most Dengue Hemorrhagic Fever Occurrence in East Java during 2015-2017

\begin{tabular}{|c|c|c|}
\hline Years & Districts/Cities & Total \\
\hline \multirow[t]{3}{*}{2015} & Pacitan District & 1,657 \\
\hline & Malang District & 1,331 \\
\hline & Bangkalan District & 1,043 \\
\hline \multirow[t]{3}{*}{2016} & Sidoarjo District & 1,708 \\
\hline & Pacitan District & 1,338 \\
\hline & Jember District & 1,298 \\
\hline \multirow[t]{3}{*}{2017} & Sampang District & 506 \\
\hline & Surabaya & 451 \\
\hline & Kediri District & 405 \\
\hline
\end{tabular}

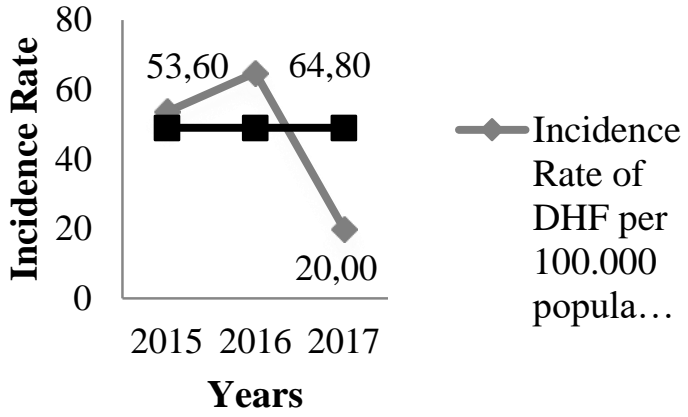

Figure 2. Incidence Rate (IR) of Dengue Hemorrhagic Fever Trend in 2015-2017

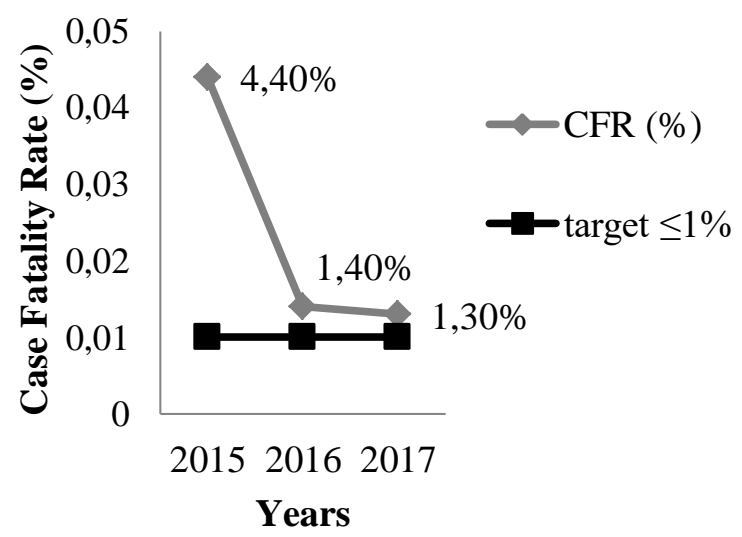

Figure 3. Case Fatality Rate (CFR) of Dengue Hemorrhagic Fever Trend during 2015-2017

The Incidence Rate in East Java in 2015-2016 was over the national rate standard. This figure suggested that the incidence of dengue cases in East Java were very high. The research conducted by Kusuma \& Sukendra (2016) stated that the spread of dengue cases occurred almost entirely in parts of the region classified as having high population density. The transmission of this disease was from one person to another. Therefore, the rate was related to population density. The results of the study were related to the research conducted by Jaya, Fauzi, Destyanugraha, Kurniawan, \& Mariyah (2017) which suggested that the primary reasons of the increasing dengue disease were uncontrolled urban planning and urbanization.

Uncontrolled urbanization triggers population density in various cities, the more overcrowded population, the more vulnerable incidences of DHF. Mosquitoes infested with the dengue virus will transmit their virus to people, causing dengue cases. To control the spreading of the disease, we its vector should be managed (Suryani, 2018). Research conducted by Prihartantie, Sulistiyani, \& Nurjazuli (2017) stated that the distance among houses influenced the spread of mosquitoes.

However, the different results were proposed according to the study conducted by Sahrir, Ishak, \& Maidin (2016) which stated there was no significant correlation between population density and the number of Aedes aegypti mosquitoes. The research employed a population density variable that was not based on ecology with clustering patterns, but it had been employed administratively. So, administrative population density did not indicate the actual population density.

According to the research by Dewi, Wiyono, \& Ahmad (2019), the high number of CFRs was caused by several factors as follows: knowledge of parents, especially regarding the characters of dengue disease; and assuming that the sufferers have an ordinary fever. The delays in handling the condition can result in death.

Factor of parents' level of knowledge plays an important role in the behavior of prevention of dengue, because with knowledge of dengue disease, parents will always pay attention to the conditions of the household as an effort to prevent so that they avoid dengue. A mother's knowledge of DHF is a result of the experiences of mothers in addition to information received by the community 
from various media as well as from health workers (Bian, 2017).

Related to CFR of DHF, Hikmah \& Kasmini (2015) stated that patients experienced delays in treatment. DHF sufferers were taken to the hospital with a weak body condition, low blood pressure, and some even had bleeding such as nosebleeds and vomiting blood. Other factors that also affected the CFR of DHF were the age, sex, income, access to health services, history of dengue fever, history of comorbidities, delay in treatment of DHF patients and the severity of the disease. Efforts to prevent dengue hemorrhagic fever are very closely related to community behavior. Individual factors include work, education, knowledge and income (Muhammad, Wardani, \& Setiawan, 2018).

The concept of the epidemiological triangle explained that occurring diseases were influenced by hosts, agents, and the environment. The high incidence of diseases could be triggered by the declined carrying capacity of the environment then causes stronger hosts to transmit diseases from agents (Koesnayani \& Hidayat, 2018). The environmental factor that affects the high incidence of dengue fever is rainfall, which is closely related to temperature and humidity. Temperature and humidity support mosquitoes in their breeding in the air temperatures of approximately 25-30 degrees Celsius as related to DHF cases will increase at a temperature of 25-27 degrees Celsius. Temperature and humidity variations influenced the reproduction activities and the survival of mosquitoes (Perwitasari, Ariati, \& Puspita, 2015). Research that was conducted by Paramita \& Mukono (2017) stated that there was a correlation between monthly rainfall and the incidence of DHF. DHF outbreaks were not always caused by rainfall intensities but were also influenced by other factors. A study that was conducted by Perwitasari, Ariati, \& Puspita (2015) noted that there was a correlation between rainfall patterns and the increasing incidence of DHF. The population density of the Aedes aegypti mosquito increases in the rainy season. Many puddles appear in the rainy season, so the mosquitos' eggs hatch faster.

Research conducted by Santoso et al (2018) suggested that the level of larvae density (density figure) was categorized in the high density category with House Index $(\mathrm{HI})=46 \%$, Container Index $(\mathrm{CI})=21 \%$, Pupa Index $(\mathrm{PI})=6 \%$, and Bruteau Index $(\mathrm{BI})=79$.

\section{Research Limitation}

The study employed a descriptive approach that utilized population rather than individual. Therefore, this study could not explain the correlation between individuals.

\section{CONCLUSION}

The number of dengue diseases occurred in East Java from 2015 to 2017 were fluctuated. Incidence Rate of DHF increased in 2016 and decreased in 2017. The number of Case Fatality Rate in East Java in 2015-2017 decreased yet was still over than the national rate standard. The majority of dengue diseases suffered by the male, and almost all districts/cities in East Java were endemic areas of DHF. The highest rate incidence of dengue during 2015-2017 occurred in 2016.

\section{CONFLICT OF INTEREST}

The authors declare that no conflict of interest in this study.

\section{ACKNOWLEDGMENT}

The author would like to extend her gratitude to the East Java Provincial Health Office as the data provider and the $\mathrm{P} 2 \mathrm{DBD}$ program holder who helped to carry out this research.

\section{REFERENCES}

Bian, S. M. (2017). Gambaran pengetahuan ibu tentang demam berdarah dengue pada anak di Puskesmas Labuan Bajo Kabupaten Manggarai Barat Nusa Tenggara Timur periode Juni tahun 2016. Jurnal Ilmiah Media Bidan, 2(1), 10-18.

Dewi, T. F., Wiyono, J., \& Ahmad, Z. S. (2019). Hubungan pengetahuan orang tua tentang penyakit DBD dengan perilaku pencegahan DBD di Kelurahan Tlogomas Kota Malang. Nursing News, 4(1), 348-358. https://doi.org/10.1021/BC049898Y

East Java Provincial Bureau Statistics. (2018). Monthly total rainfall in East Java Province, 2006-2017. East Java Provincial Bureau Statistics. Surabaya.

East Java Provincial Health Office. (2016). East Java province health profile 2015. Surabaya: East Java Provincial Health Office.

East Java Provincial Health Office. (2017). East Java province health profile 2016. Surabaya: East Java Provincial Health Office 
East Java Provincial Health Office. (2018). East Java province health profile 2017. Surabaya: East Java Provincial Health Office.

Ernawati, Bratajaya, C. N., \& Martina, S. E. (2018). Gambaran praktik pencegahan demam berdarah dengue (DBD) di wilayah endemik DBD. Jurnal Keperawatan, 9(1), $17-24$.

Francisco, F., Kaunang, W. P. ., \& Kekenusa, J. S. (2018). Hubungan antara faktor lingkungan biologis dengan kejadian penyakit demam berdarah dengue (DBD) di wilayah kerja Puskesmas Tikala Manado. Community Health, 2(5), 48-62.

Hikmah, M., \& Kasmini, O. W. H. (2015). Faktor yang berhubungan dengan kejadian kematian akibat demam berdarah dengue. Unnes Journal of Public Health, 4(4), 180-189. https://doi.org/10.15294/ujph.v4i4.9693

Jaya, M. L. H. D., Fauzi, A., Destyanugraha, R., Kurniawan, R., \& Mariyah, S. (2017). Deteksi dini kasus demam berdarah dengue berdasarkan faktor cuaca di DKI Jakarta menggunakan metode zero truncated negative binomial. Buletin Penelitian Kesehatan, 45(3), 161-168.

Koesnayani, A. S., \& Hidayat, A. K. (2018). Hubungan antara pola curah hujan dengan kejadian DBD di Kota Tasikmalaya tahun 2006-2015 (kajian jumlah curah hujan dan hari hujan). Jurnal Siliwangi, 4(1), 14-19.

Kusuma, A. P., \& Sukendra, D. M. (2016). Analisis spasial kejadian demam berdarah dengue berdasarkan kepadatan penduduk. Unnes Journal of Public Health, 5(1), 48-56. https://doi.org/10.15294/ujph.v5i1.9703

Ministry of Health RI. (2017). Dengue prevention and control program guidelines in Indonesia. Jakarta: Ministry of Health RI.

Muhammad, F., Wardani, D. W. S. R., \& Setiawan, G. (2018). Hubungan pengetahuan dan status sosial ekonomi terhadap upaya pencegahan demam berdarah dengue (DBD) di Desa Pajaresuk Kecamatan Pringsewu Kabupaten Pringsewu. Majority, 7(3), 68-72.

Novrita, B., Mutahar, R., \& Purnamasari, I. (2017). The analysis of incidence of dengue hemorrhagic fever in public health center of Celikah Ogan Komering Ilir Regency. Jurnal Ilmu Kesehatan Masyarakat, 8(1), 20-28.

Nurrochmawati, I., Dharmawan, R., \& Pawito. (2017). Bilogical, physical, social, and environmental factors associated with dengue hemorrhagic fever in Nganjuk, East Java. Journal of Epidemiology and Public Health,
2(2),

93-105.

https://doi.org/10.26911/jepublichealth.2017. 02.02.01

Paramita, R. M., \& Mukono, J. (2017). Hubungan kelembapan udara dan curah hujan dengan kejadian demam berdarah dengue di Puskesmas Gunung Anyar 2010-2016. The Indonesian Journal of Public Health, 12(2), 202-212.

https://doi.org/10.20473/ijph.v12i1.2017.202 $-212$

Perwitasari, D., Ariati, J., \& Puspita, T. (2015). Kondisi iklim dan pola kejadian demam berdarah dengue di Kota Yogyakarta tahun 2004-2011. Media Penelitian dan Pengembangan Kesehatan, 25(4), 243-248. https://doi.org/10.22435/mpk.v25i4.4591.243 $-248$

Prihartantie, I. T., Sulistiyani, \& Nurjazuli. (2017). Hubungan faktor lingkungan dan faktor demografi dengan kejadian DBD di Kota Salatiga. Jurnal Kesehatan Masyarakat (eJournal), 5(1), 2356-3346.

Rahmawati, U., Joko, T., \& Nurjazuli. (2018). Hubungan antara praktik $3 \mathrm{M}$ dan faktor lingkungan fisik rumah dengan kejadian demam berdarah dengue di wilayah kerja Puskesmas Kayen Kabupaten Pati. Jurnal Kesehatan Masyarakat (e-Journal), 6(6), 378-385.

Sahrir, N., Ishak, H., \& Maidin, A. (2016). Pemetaan karakteristik lingkungan dan densitas nyamuk Aedes Aegypti berdasarkan status endemisitas DBD di Kecamatan Kolaka. JST Kesehatan, 6(1), 70-75.

Santoso, Taviv, Y., Mayasari, R., Margarethy, I., Wempi, I. G., \& Marini. (2018). Hubungan karakteristik kontainer dengan keberadaan jentik aedes aegypti pada kejadian luar biasa demam berdarah dengue: studi kasus di Kabupaten Ogan Komering Ulu. Jurnal Vektor Penyakit, 12(1), 9-18. https://doi.org/10.22435/vektorp.v1 i . 21 2299

Suryani, E. T. (2018). The overview of dengue hemorrhagic fever cases in Blitar City from 2015-2017. Jurnal Berkala Epidemiologi, 6(3), 260-267. https://doi.org/10.20473/jbe.v6i3.2018.260267 